\title{
RAMP2 Gene
}

National Cancer Institute

\section{Source}

National Cancer Institute. RAMP2 Gene. NCI Thesaurus. Code C127150.

This gene is involved in adrenomedullin binding and signaling. 